\title{
Fast identification of the antibacterial in Aspergillus species
}

\author{
XIAOJING WANG ${ }^{1}$ \\ LIXIN DUAN ${ }^{2}$ \\ SHENGNAN YANG ${ }^{1}$ \\ ZHENGFU ZHOU ${ }^{1}$ \\ BAOQING DUN ${ }^{3 *}$ \\ ${ }^{1}$ Biotechnology Research Institute \\ Chinese Academy of Agricultural Sciences \\ Beijing 100081, China \\ 2 Institute of Botany, Chinese Academy of Sciences, \\ Beijing 100093, China \\ ${ }^{3}$ Institute of Crop Science \\ Chinese Academy of Agricultural Sciences \\ Beijing 100081, China \\ *Correspondence: \\ (Baoqing Dun, e-mail: dunbaoqing@caas.cn) \\ No nonstandard abbreviations
}

Key words: Antibacterial activity, HPLC, Aspergillus, Bioactive metabolites

Received April 15, 2016

Revised July 15, 2016.

Accepted July 28, 2016.

\section{Abstract:}

Background and Purpose: Aspergillus genus biosynthesize a large number of metabolites with wide-ranging bioactivities, but how to target the active compounds quickly and accurately? In this work, we provide a strategy to fast identify bioactive metabolites in fungi with similar morphology but different antimicrobial activities.

Materials and Methods: Combined with High Performance Liquid Chromatography (HPLC) profiles and bioactivity screening of fungal extracts, three Aspergillus sp. strains YSN038, YSN052 and YSNO64 were studied. The bacteria Bacillus pumilus, Bacillus subtilis, Staphylococcus aureus, Kocuria rhizophila, Escherichia coli and Ralstonia solanacearum were used for antibiotic assay.

Results: Three strains showed the similar morphology, but the crude extracts of YSNO38 and YSNO64 displayed antibacterial activities against B. pumilus, B. subtilis, S. aureus and K. rhizophila, whereas YSN052 had not. The compound contributed to antibacterial activity in vitro was rapidly identified, isolated and characterized. Compound 3 connected with specific HPLC peak should be the antibiotic substance by analysis of HPLC profiles, and was confirmed after the following antimicrobial tests. The compound was elucidated as butyrolactone I based on nuclear magnetic resonance(NMR) and mass spectrometry (MS) data, and showed various biological activities.

Conclusions: Our study has significant scope on targeting antibacterial metabolites. The described method could also be used as a rapid and costeffective tool for screening other bioactivity products. As such, this article could offer a fast approach to isolate drug-lead compounds from microorganisms.

\section{INTRODUCTION}

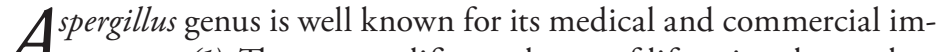
$A_{\text {portance (1). They are prolific producers of lifesaving drugs, dev- }}$ astating toxins, or mass produced industrial enzymes (2). Many clinically beneficial secondary metabolites are produced by Aspergillus genus, such as lovastatin, terrein, griseofulvin. Lovastatin, also known as mevinolin or monacolin $\mathrm{K}$, is effective clinical drug used for reducing serum cholesterol and slowing the progression of atherosclerosis. Lovastatin and its related compounds inhibit cholesterol synthesis by inhibiting the rate-limiting step in cellular cholesterol biosynthesis (3). Terrein, one of Aspergillus major secondary metabolites has ecological, antimicrobial, antiproliferative and antioxidative activities (4). Some strains of Aspergillus can biosynthesize gluconic acid which is a bulk 
chemical with many uses in the food, beverage and other industries (5).

Aspergillus genomes contain a large number of secondary metabolite biosynthetic genes. However, only a few products can be actually determined. For example, there are 33-79 putative polyketide synthase (PKS) and nonribosomal peptide (NRPS) encoding genes in sequenced Aspergillus genomes and only $9 \%-30 \%$ of these genes can connect with their products (3). This information reveals that many compounds in Aspergillus species are waiting for discovery.

The traditional chemical analysis of fungal secondary metabolite is a time-consuming and labour-consuming process. First, a large number of strains are isolated, then the secondary metabolites produced by those strains are evaluated by bioassay, last, the strain with biologically activity is large-scale fermented, and every compound of the crude extraction of the fermentation is purified for screening activated compound. This method cannot target the activated compound rapidly and accurately, and it is imperative to find a method that could detect valuable compound from microorganism rapidly and accurately.

Herein, we described a fast antibacterial identification strategy. To screen the antimicrobial metabolites against Bacillus pumilus, Bacillus subtilis, Staphylococcus aureus, Kocuria rhizophila, Escherichia coli, and Ralstonia solanacearum, three Aspergillus strains YSN038, YSN052 and YSN064 with similar morphology but different antibacterial activity were investigated. By comparing the HPLC profiles and appropriate antibiotic activities of the crude extracts, the activated compound was identified directly. This study provides a method to fast identify bioactive metabolites in the similar microbial genus.

\section{MATERIALS AND METHODS}

\section{Strains and Culture Conditions}

YSN038, YSN052 and YSN064 were maintained on potato dextrose agar (PDA) plates containing $0.3 \%$ potato extract, $2 \%$ glucose, and $1.5 \%$ agar. Freshly inoculated plates were incubated at $30^{\circ} \mathrm{C}$ for 10 days. The test bacteria used in this study were Bacillus pumilus (CGMCC 1.3533), Bacillus subtilis (ATCC 10626), Staphylococcus aureus (ATCC 25923), Kocuria rhizophila (CGMCC 1.2156), Escherichia coli (MG1655), and Ralstonia solanacearum (ACCC 11608) stocked in our lab. B. subtilis, $S$. aureus and E. coli were grown on LB medium at $37^{\circ}$, $B$. pumilus, K. rhizophila and $R$. solanacearum were grown on NA medium at $30^{\circ}$.

\section{Analysis of 185 rDNA}

The genomic DNA of YSN038, YSN052 and YSN064 were extracted from three to five days PDA plates by Phenol: chloroform: isopentanol, precipitated with ethanol, and resuspended in TE buffer (6). The quantity of DNA was measured by Thermo Scientific Nano Drop spectrophotometer. The sequences of consensus primers used for the PCR amplification of $18 \mathrm{~S}$ rDNA fragment were ITS4 (TCCTCCGCTTATTGATATGC) and ITS5 (GGAAGTAAAAGTCGTAACAAGG). Phylogenetic tree was constructed using the Neighbor joining method with bootstrapping 500 times by MEGA 6.0. The partial $18 \mathrm{~S}$ rDNA nucleotide sequences of YSN038, YSN052, and YSN064 has been submitted to GenBank under accession number KT375566, KT375567 and KT375568.

\section{Extraction and isolation}

Agar surface culture fermentations were done by growing YSN038, YSN052 and YSN064 on 20 PDA plates for 10 days, then they were extracted with methanol in 1:2 (v/v) for three times. The crude extracts were obtained after removal of the organic solvent by the rotary evaporator. The extracts were weighed and preserved in sterile bottles at $4^{\circ}$.

Crude Extractions were analyzed by reversed phase HPLC on a Shimadzu DGU-20A5R equipped with a Kromasil C18 column (100-5-C18). HPLC conditions for the analysis of crude extracts were a linear $30-80 \%$ gradient of $\mathrm{CH}_{3} \mathrm{OH}$ in $\mathrm{H}_{2} \mathrm{O}$ over $8 \mathrm{~min}, 80 \% \mathrm{CH}_{3} \mathrm{OH}$ in $\mathrm{H}_{2} \mathrm{O}$ for 10 min, a linear $80-95 \%$ gradient of $\mathrm{CH}_{3} \mathrm{OH}$ in $\mathrm{H}_{2} \mathrm{O}$ over $1 \mathrm{~min}, 95 \% \mathrm{CH}_{3} \mathrm{OH}$ in $\mathrm{H}_{2} \mathrm{O}$ for $5 \mathrm{~min}$, a linear $95-30 \%$ gradient of $\mathrm{CH}_{3} \mathrm{OH}$ in $\mathrm{H}_{2} \mathrm{O}$ over 1 min, and $30 \% \mathrm{CH}_{3} \mathrm{OH}$ in $\mathrm{H}_{2} \mathrm{O}$ for $3 \mathrm{~min}$; flow rate of $0.8 \mathrm{ml} /$ $\mathrm{min}$; detection at $280 \mathrm{~nm}$. Scaled-up cultivation of fungi strains for 50 plates, and isolated of compounds through ODS column chromatography (YMC, $40 \mu \mathrm{m}$ ), silica gel chromatography (Merck, $40 \mu \mathrm{m}$ ) and semi-preparative HPLC (Waters, Delta Prep 4000, $10 \times 250 \mathrm{~mm}$ ). ${ }^{1} \mathrm{H}$ NMR, ${ }^{13} \mathrm{C}$ NMR and heteronuclear multiple-bond correlation spectroscopy (HMBC) spectra were recorded in dimethyl sulfoxide (DMSO) solution on a Bruker AV-500 instrument at $500 \mathrm{MHz}$ for ${ }^{1} \mathrm{H} \mathrm{NMR}$ and $125 \mathrm{MHz}$ for ${ }^{13} \mathrm{C}$ NMR. The chemical shift values $\left(^{\circ}\right)$ were given in parts per million (ppm), and the coupling constants were given in hertz. High resolution electrospray ionization mass spectrometry (ESIMS) were obtained with an Agilent 1100 series LC/MSD ion trap mass spectrometer. MS analysis was performed in positive mode using full scan mode. The conditions of the ESI source were as follows: capillary voltage, $3.0 \mathrm{kV}$; drying gas $\left(\mathrm{N}_{2}\right)$ flow rate, $6.0 \mathrm{~L} /$ min, temperature, $330^{\circ}$; nebulizing gas $\left(\mathrm{N}_{2}\right)$ pressure, 40 psi; flow rate, $0.3 \mathrm{ml} / \mathrm{min}$.

\section{Antimicrobial activity assays}

The antimicrobial activity was screened by the method of disk diffusion. The crude extracts were prepared in methanol. The amount of crude extracts was adjusted to $80 \mu \mathrm{g}$ on a $7 \mathrm{~mm}$ filter paper disk. The completely dried disks with crude extract were attached to the plates 
lawned with $200 \mathrm{ml}$ test bacteria. The plates were labeled and incubated at $30^{\circ}$ (B. pumilus, K. rhizophila and $R$. solanacearum) or $37^{\circ}$ (B. subtilis, S. aureus and E. coli) for 18 to $24 \mathrm{~h}$. After incubation, clear zones of inhibition around the disks indicated the sensitivity rate of the test bacteria to each extract and diameters of the clear zones were taken as index of the degree of sensitivity. Tests were carried out in three times. Disk without any crude extract was used as negative control, and kanamycin as positive control. The inhibitory zones of extracts were expressed as the mean \pm standard deviation (7).

Microdilution method using 96-well microplate was performed to quantify the antimicrobial activity of compound 3 . The stock solution was made by dissolving 200 $\mu \mathrm{g}$ compound 3 in $1 \mathrm{ml}$ methanol. $10 \mu \mathrm{l}$ of compound 3 solution $(200 \mu \mathrm{g} / \mathrm{ml})$ was added into the second row of microplate, two-fold dilutions of compound 3 (200-0.39 $\mu \mathrm{g} / \mathrm{ml}$ ) was made by dispensing the solutions into the 3-11 wells. $100 \mu \mathrm{l}$ of medium was added into the first row as the BLANK and $10 \mu \mathrm{l}$ of methanol was added into the last row as the control. $90 \mu \mathrm{l}$ of test strain suspension inoculated into all the wells except the first row. The plates were tested after incubated at $30^{\circ}$ or $37^{\circ}$ for 18 to $24 \mathrm{~h}$. Results were registered in an ELISA reader, and $\mathrm{IC}_{50}$ were calculated graphically from concentration-inhibition curves (8).

\section{RESULTS}

\section{Phylogenetic analysis of fungal strains}

The genomic DNAs of YSN038, YSN052 and YSN064 were extracted, and $18 \mathrm{~S}$ rDNA fragments were amplified using universal primers ITS4 and ITS5. The alignment of $18 \mathrm{~S}$ rDNA showed that three strains had high identity with Aspergillus genus at the range of $96.8 \%$ to $99.8 \%$. These $18 \mathrm{~S}$ rDNA sequences had high identity with Aspergillus neoafricanus RRL 2399 and Aspergillus terreus DF12079 particularly, so these fungal strains were defined as Aspergillus sp.YSN038, Aspergillus sp.YSN052, and Aspergillus sp. YSN064 (Table 1). Phylogenetic tree was shown in Figure 1 below.

Table 1: Identity between YSN038, YSN052, YSN064 and other Aspergillus genus

\begin{tabular}{|lccc|}
\hline & YSN038 & YSN052 & YSN064 \\
\hline Aspergillus terreus DF12079 & $99.5 \%$ & $99.7 \%$ & $99.7 \%$ \\
Aspergillus candidus CY104 & $96.8 \%$ & $97.0 \%$ & $97.0 \%$ \\
Aspergillus alabamensis NRRL 29810 & $99.2 \%$ & $99.4 \%$ & $99.4 \%$ \\
Aspergillus flavus TUHT153 & $97.0 \%$ & $97.3 \%$ & $97.3 \%$ \\
Aspergillus neoafricanus RRL 2399 & $99.8 \%$ & $99.8 \%$ & $99.8 \%$ \\
Aspergillus ochraceus MP2 & $97.6 \%$ & $97.4 \%$ & $97.4 \%$ \\
Aspergillus pseudoterreus CICC2690 & $99.1 \%$ & $99.1 \%$ & $99.1 \%$ \\
\hline
\end{tabular}

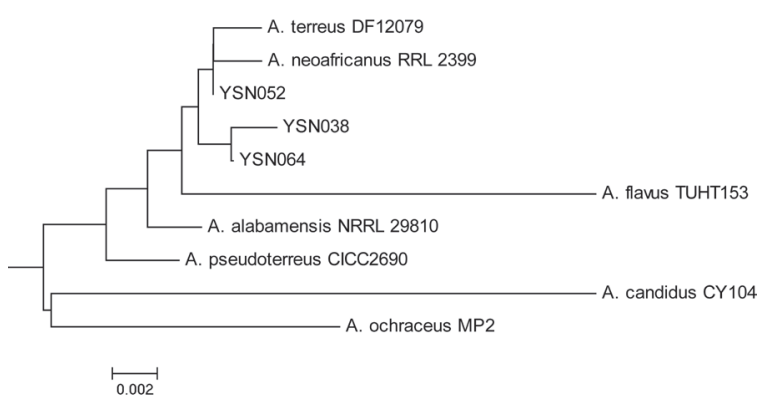

Figure 1: Phylogenetic tree of YSN038, YSN052, YSN064 and other Aspergillus species group

\section{Three fungal strains displayed different antimicrobial activity}

Three strains showed similar morphology, they were pale brown or brown, and get darker, dense texture, flat or with radial grooves on PDA plate after aging. In some cases, they were able to become floccose.

20 PDA plates grown on YSN038, YSN052 and YSN064 were successively extracted with methanol to afford the crude extracts $(0.31 \mathrm{~g}, 0.25 \mathrm{~g}$ and $0.26 \mathrm{~g}$ on YSN038, YSN052, YSN064). Disk diffusion method was performed to test antimicrobial activity against $B$. pumilus, B. subtilis, S. aureus, K. rhizophila, E. coli and R. solanacearum. Positive results were observed with $80 \mu \mathrm{g} /$ disk crude extracts of YSN038 and YSN064 on B. pumilus, B. subtilis, S. aureus, and $K$. rhizophila, but no effect on $E$. coli and $R$. solanacearum. The inhibitory zones were shown below. The crude extract of YSN052 displayed no effect on all the test bacteria (Table 2 and Figure 2).

A: HPLC profiles of crude extracts of YSN038, YSN052 and YSN064. 2 and $\mathbf{4}$ have no antibacterial activities. 3 has antibacterial activity. B: Crude extracts of YSN038 and YSN064, but not YSN052, can inhibit the growth of B. pumilus, B. subtilis, S. aureus, and K. rhizophila.

\section{Identification antibacterial activities and structures of the compounds}

YSN038, YSN052 and YSN064 displayed different antibacterial activities to the test bacteria implied that they produced different secondary metabolites. HPLC profiles showed that the crude extracts of YSN038, YSN052 and YSN064 had four main peaks of 1, 2, 3, 4, two main peaks of 2, 4, and three main peaks of 2, 3, 4 respectively. YSN052 could not inhibit the growth of $B$. pumilus, B. subtilis, S. aureus, and K. rhizophila, indicated that peaks $\mathbf{2}$ and $\mathbf{4}$ have no contribution to antibacterial activity, which means peaks $\mathbf{1}$ and/or $\mathbf{3}$ in YSN038, and peak 3 in YSN064 should had antibacterial ability. YSN064 with peaks 2, 3 and $\mathbf{4}$ exhibited antibacterial activities, implied that peak $\mathbf{3}$ should have the antibiotic 
Table 2: Inhibitory zones of YSNO38, YSN052, and YSNO64 crude extracts $(80 \mu \mathrm{g} /$ disk)

\begin{tabular}{|lccc|}
\hline \multirow{2}{*}{$\begin{array}{l}\text { Bacteria for } \\
\text { antibacterial test }\end{array}$} & \multicolumn{3}{c|}{ Inhibitory zones (mm) } \\
\cline { 2 - 4 } & YSN038 & YSN052 & YSN064 \\
\hline B. pumilus & $13.2 \pm 0.8$ & NA & $13.1 \pm 0.3$ \\
B. subtilis & $13 \pm 0.4$ & NA & $15.3 \pm 0.4$ \\
S. aureus & $11.2 \pm 0.2$ & NA & $11.9 \pm 0.7$ \\
K. rhizophila & $10.2 \pm 0.2$ & NA & $13.2 \pm 0.2$ \\
E. coli & NA & NA & NA \\
R. solanacearum & NA & NA & NA \\
\hline
\end{tabular}

The inhibitory zones of extracts were expressed as the mean \pm standard deviation.

$\mathrm{NA}=$ not active

activity (Figure 1). Also we were not sure if compound 1 in YSN038 had activity.

In order to confirming the compounds' antibacterial activities and structures, 50 PDA plates grown with YSN038 were extracted with methanol to gather $1.8 \mathrm{~g}$ crude extracts. The crude extract was subjected to ODS column chromatography and eluted with $\mathrm{MeOH}$ and $\mathrm{H}_{2} \mathrm{O}$ (Fraction A, $\mathrm{H}_{2} \mathrm{O}, 100 \mathrm{ml}$; Fraction B, 50/50, 100 $\mathrm{ml}$; Fraction C, 55/45, $100 \mathrm{ml}$; Fraction D, 60/40, $100 \mathrm{ml}$; Fraction E, 65/35, $100 \mathrm{ml}$; Fraction F, MeOH, $100 \mathrm{ml}$; $\mathrm{v} / \mathrm{v})$. Compound $\mathbf{1}(7.0 \mathrm{mg}$, retention time: $17.5 \mathrm{~min})$ and compound 2 (7.0 mg, retention time: $17.5 \mathrm{~min})$ were purified from fraction B by reversed phase HPLC $(\mathrm{MeOH} /$ $\mathrm{H}_{2} \mathrm{O}=45 / 55$, v/v). Compound 3 (7.9 mg) was obtained from fraction $\mathrm{C}$ through reversed phase HPLC $(\mathrm{MeOH} /$ $\mathrm{H}_{2} \mathrm{O}=55 / 45, \mathrm{v} / \mathrm{v}, 20 \mathrm{~min}$ ) and Silica gel column chromatography eluted with hexane/ethyl acetate mixture solvent $(1 / 1, \mathrm{v} / \mathrm{v})$. Compound $\mathbf{4}(5.3 \mathrm{mg})$ was prepared by reversed phase HPLC $\left(\mathrm{MeOH} / \mathrm{H}_{2} \mathrm{O}=55 / 45\right.$, v/v, $\left.25 \mathrm{~min}\right)$.
A

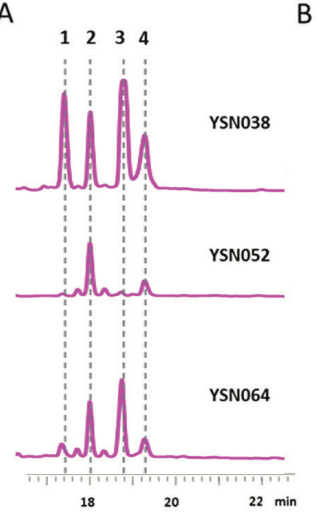

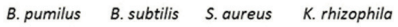
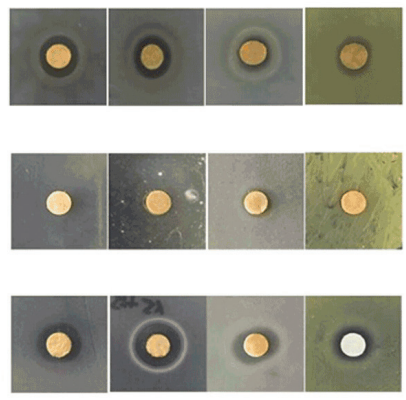

Figure 2: HPLC profiles and antibacterial activities of YSNO38, YSN052 and YSN064 crude extracts
Table 3: Inhibitory zones of compound 1, 3 (80 $\mu \mathrm{g} /$ disk) and $I C_{50}$ of compound 3 of $Y S N 038$

\begin{tabular}{|lccc|}
\hline $\begin{array}{l}\text { Bacteria for } \\
\text { antibacterial test }\end{array}$ & \multicolumn{2}{c|}{ Inhibitory zones $(\mathrm{mm})$} & $I C_{50}(\mu \mathrm{g} / \mathrm{ml})$ \\
\cline { 2 - 4 } & compound 1 & compound 3 & compound 3 \\
\hline B. pumilus & NA & $17.2 \pm 0.3$ & $15.6 \pm 0.2$ \\
B. subtilis & NA & $15.4 \pm 0.5$ & $48.8 \pm 0.5$ \\
S. aureus & NA & $14.1 \pm 0.2$ & $62.3 \pm 0.3$ \\
K. rhizophila & NA & $11 \pm 0.2$ & $62.3 \pm 0.2$ \\
E. coli & NA & NA & NA \\
R. solanacearum & NA & NA & NA \\
\hline
\end{tabular}

The inhibitory zones of extracts were expressed as the mean \pm standard deviation.

$\mathrm{NA}=$ not active

The antibacterial activity confirmed by disk diffusion method. Compound $\mathbf{3}$ showed same bioactivity as that of crude extraction, but compound $\mathbf{1}$ had no bioactivity(table 3). $\mathrm{IC}_{50}$ of compound 3 were determined and were from $15.6 \mu \mathrm{g} / \mathrm{ml}$ to $62.3 \mu \mathrm{g} / \mathrm{ml}$ to B. pumilus, B. subtilis, $S$. aureus and $K$. rhizophila seperatively (table 3 ). Compound 3 had no inhibitory activity to $E$. coli and $R$. solanacearum with the concentration of $0.39-200 \mu \mathrm{g} / \mathrm{ml}$.

The molecular formula of $\mathbf{3}$ was determined as $\mathrm{C}_{24} \mathrm{H}_{24} \mathrm{O}_{7}$ by high-resolution electrospray ionization mass spectrometry (HRESIMS), which gave a quasi-molecular ion peak at $m / z: 425.1647$ (calcd for $\mathrm{C}_{24} \mathrm{H}_{25} \mathrm{O}_{7}[\mathrm{M}+\mathrm{H}]^{+}$, 425.1596). The ${ }^{1} \mathrm{H}$ NMR spectrum showed a set of four ortho-coupled aromatic hydrogens at $\delta 7.50(\mathrm{~d}, 2 \mathrm{H}, J=$ $8.8 \mathrm{~Hz})$ and $6.87(\mathrm{~d}, 2 \mathrm{H}, J=8.8 \mathrm{~Hz})$, suggesting a 1 , 4 -substituted aromatic ring. Other three aromatic hydrogens at $\delta 6.53(\mathrm{~d}, 1 \mathrm{H}, J=6.8 \mathrm{~Hz}), 6.47\left(\mathrm{dd}, 1 \mathrm{H}, J_{1}=6.8\right.$ $\left.\mathrm{Hz}, J_{2}=2.4 \mathrm{~Hz}\right)$, and $6.36(\mathrm{~d}, 1 \mathrm{H}, J=2.4 \mathrm{~Hz})$, indicating a 1,3,5-substituted aromatic ring. And hydrogens signals at $\delta 1.53\left(\mathrm{~s}, 3 \mathrm{H},-\mathrm{CH}_{3}\right), 1.62\left(\mathrm{~s}, 3 \mathrm{H},-\mathrm{CH}_{3}\right), 2.99(\mathrm{~d}, 2 \mathrm{H}$, $\left.J=6.8 \mathrm{~Hz},-\mathrm{CH}_{2}-\right)$, and a olefinic proton at $5.01(\mathrm{~m}, 1 \mathrm{H})$ indicated existing a isopentene group. In ${ }^{13} \mathrm{C}$ NMR spectrum showed 24 carbon signals, and the signals of $\delta 127.3$ (C-7), 138.1 (C-8), 168.0 (C-9) and 84.7 suggested a unsaturated lactone grouop existing. The NMR spectrum were same to butyrolactone $\mathrm{I}(9)$, thus compound $\mathbf{3}$ was elucidated as butyrolactone I (Table 4 and Figure 3).

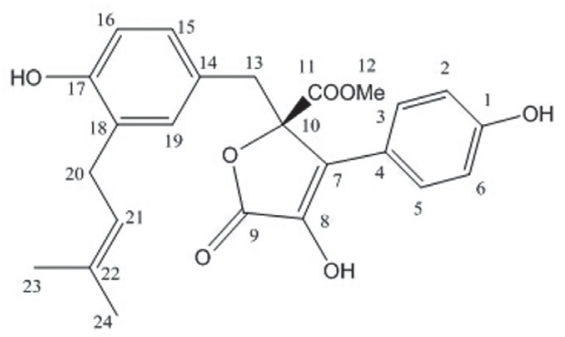

Figure 3: Structure of compound 3 
Table 4: the ${ }^{1} \mathrm{H}-,{ }^{13} \mathrm{C}-\mathrm{NMR}$ and $\mathrm{HMBC}$ data of compound 3 in DMSO-d

\begin{tabular}{|c|c|c|c|c|}
\hline \multirow[t]{2}{*}{ No. } & \multicolumn{3}{|c|}{$\begin{array}{c}\text { Compound } 3 \\
\left(\mathrm{DMSO}-d_{6}, \delta \text { in ppm, } J \text { in } \mathrm{Hz}\right)\end{array}$} & \multirow{2}{*}{$\begin{array}{l}\text { Butyrolactone } \\
\text { I* (DMSO- } \\
d_{6}, \delta \text { in ppm) } \\
\delta_{\mathrm{C}}\end{array}$} \\
\hline & $\delta_{\mathrm{C}}$ & $\delta_{\mathrm{H}}$ & Key HMBC & \\
\hline 1 & 157.9 & & & 157.9 \\
\hline 2 & 115.7 & $6.87(\mathrm{~d}, 1 \mathrm{H}, 8.8)$ & $\mathrm{C}_{6}, \mathrm{C}_{4}, \mathrm{C}_{1}$ & 115.8 \\
\hline 3 & 128.7 & $7.50(\mathrm{~d}, 1 \mathrm{H}, 8.8)$ & $\mathrm{C}_{5}, \mathrm{C}_{7}, \mathrm{C}_{1}$ & 128.8 \\
\hline 4 & 121.1 & & & 121.1 \\
\hline 5 & 128.7 & $7.50(\mathrm{~d}, 1 \mathrm{H}, 8.8)$ & $\mathrm{C}_{3}, \mathrm{C}_{7}, \mathrm{C}_{1}$ & 128.8 \\
\hline 6 & 115.7 & $6.87(\mathrm{~d}, 1 \mathrm{H}, 8.8)$ & $\mathrm{C} 2, \mathrm{C}_{4}, \mathrm{C}_{1}$ & 115.8 \\
\hline 7 & 127.3 & & & 127.5 \\
\hline 8 & 138.1 & & & 138.1 \\
\hline 9 & 168.0 & & & 167.9 \\
\hline 10 & 84.7 & & & 84.8 \\
\hline 11 & 169.8 & & & 169.8 \\
\hline 12 & 53.5 & $3.74(\mathrm{~s}, 3 \mathrm{H})$ & $\mathrm{C}_{11}$ & 53.4 \\
\hline 13 & 38.1 & $3.36(\mathrm{~s}, 2 \mathrm{H})$ & $\mathrm{C}_{10}, \mathrm{C}_{11}, \mathrm{C}_{14}$ & 38.1 \\
\hline 14 & 123.1 & & & 123.1 \\
\hline 15 & 128.4 & $\begin{array}{c}6.47(\mathrm{dd}, 1 \mathrm{H}, \\
8.4,2.4)\end{array}$ & $\mathrm{C}_{17}, \mathrm{C}_{19}, \mathrm{C}_{13}$ & 128.4 \\
\hline 16 & 114.1 & $6.53(\mathrm{~d}, 1 \mathrm{H}, 8.4)$ & $\mathrm{C}_{17}, \mathrm{C}_{18}, \mathrm{C}_{14}$ & 114.1 \\
\hline 17 & 153.8 & & & 153.8 \\
\hline 18 & 126.4 & & & 126.5 \\
\hline 19 & 130.9 & $6.36(\mathrm{~d}, 1 \mathrm{H}, 2.4)$ & $\mathrm{C}_{17}, \mathrm{C}_{18}, \mathrm{C}_{15}$ & 130.1 \\
\hline 20 & 27.5 & $2.99(\mathrm{~d}, 2 \mathrm{H}, 6.8)$ & $\mathrm{C}_{21}, \mathrm{C}_{18}, \mathrm{C}_{22}, \mathrm{C}_{17}$ & 27.6 \\
\hline 21 & 122.3 & $5.01(\mathrm{~m}, 1 \mathrm{H})$ & $\mathrm{C}_{23}, \mathrm{C}_{24}, \mathrm{C}_{20}$ & 122.4 \\
\hline 22 & 131.4 & & & 131.4 \\
\hline 23 & 25.5 & $1.62(\mathrm{~s}, 3 \mathrm{H})$ & $\mathrm{C}_{21}, \mathrm{C}_{22}$ & 25.5 \\
\hline 24 & 17.5 & $1.53(\mathrm{~s}, 3 \mathrm{H})$ & $\mathrm{C}_{21}, \mathrm{C}_{22}$ & 17.5 \\
\hline
\end{tabular}

*reference:(9)

\section{DISCUSSIONS}

Secondary metabolism is dispensable to normal metabolism, it is widely variable in occurrence, and may have a readily apparent biological function or not. Under conditions of nutrient limitation, such as deprivation of easily assimilated carbon, nitrogen, or phosphorus sources, the organism enters a period of slower growth, morphological alterations, and changes in metabolism known as secondary metabolism. Therefore, many secondary metabolite products cannot be actually discovered even so many genes mined in genomes. Due to the growth conditions and low abundance of the metabolites, the products of most secondary metabolite biosynthetic genes are still unknown. If we change growth conditions or do large scale fermentation, the metabolites not identified maybe detected using our strategy.

Butyrolactone I and related compounds were a class of important secondary metabolite in Aspergillus, which holds a core structure of 3-Phenyl-4-Benzyl- $\delta$-butyrolactone, the chemical structure is $\delta$-oxo- $\delta$-(p-hydroxyphenyl)$\delta$-(p-hydroxy-m-3,3-dimethylallylbenzyl)- $\delta$-methoxycarbonyl- $\delta$-butyrolactone I (10). Butyrolactone I inhibits eukaryotic cyclin-dependent kinases, protein kinases that control cell cycle progression in all eukaryotes (10). Wang investigated butyrolactone I inhibits H1N1, the cell toxicity is lower at the same time, shows that the compound might be a candidate for antiviral flu drug. The effects of butyrolactone I on the prevention of germinal vesicle breakdown, changes of microtubular structures, and development of porcine and bovine oocytes was studied (11, 12), but the inhibition effect is temporary and reversible (13). A large number of derivative of butyrolactone I (butyrolactone II-VII and its sulphuric acid derivatives) (9, 14-16) also showed various biological activity, which highlights the value of these compounds. Isobutyrolactone II had evident antiviral activity towards HSV-1 with $\mathrm{IC}_{50}$ values of $21.8 \pm 0.8 \mu \mathrm{g} / \mathrm{ml}$, and butyrolactone $\mathrm{V}$ had potent antifouling activity with $\mathrm{EC}_{50}$ values of $22.1 \pm 0.8$ $\mu \mathrm{g} / \mathrm{ml}$ towards barnacle Balanus amphitrite larvae (17).

Aspergillus sp. YSN038,YSN052 and YSN064 displaying different inhibitory activities on $B$. pumilus, B. subtilis, S. aureus, $K$. rhizophila, E. coli and $R$. solanacearum provides an opportunity to quickly identify the antibacterial compound. After comparison with HPLC profiles and antibacterial activities of three Aspergillus sp. strains, the antibacterial compound $\mathbf{3}$ was quickly targeted, and the antibacterial activity was confirmed too. In the course of fungal secondary metabolite study, the researchers found that even morphological similar, strains could also have different spectrum of secondary metabolites. We can take advantage of this difference to find the active substance. Our method provides a strategy to fast identify bioactive metabolites in Aspergillus genus, and our study has significant scope on targeting antimicrobial metabolites and other activity compounds. This method also provides a useful tool for drug discovery.

Acknowledgements: This study was funded by National Basic Research (973) Program of China (2015CB755703) and 948 program (2016-X43) of Ministry of Agriculture of China.

Conflict of Interest: The authors declare that they have no conflict of interest.

\section{REFERENCES}

1. Pi BR, Yu DL, Dai FW, Song XM, Zhu CY, Li HY,Yu YS. 2015 A Genomics Based Discovery of Secondary Metabolite Biosynthetic Gene Clusters in Aspergillus ustus. PloS one. 10. https://doi.org/10.1371/journal.pone.0116089

2. Sanchez JF, Somoza AD, Keller NP,Wang CCC. 2012 Advances in Aspergillus secondary metabolite research in the post-genomic era. Natural product reports. 29: 351-371. https://doi.org/10.1039/c2np00084a 
3. Guo CJ,Wang CCC. 2014 Recent advances in genome mining of secondary metabolites in Aspergillus terreus. Front Microbiol. 5. https://doi.org/10.3389/fmicb.2014.00717

4. Zaehle C, Gressler M, Shelest E, Geib E, Hertweck C,Brock M. 2014 Terrein Biosynthesis in Aspergillus terreus and Its Impact on Phytotoxicity. Chem Biol. 21: 719-731.

https://doi.org/10.1016/j.chembiol.2014.03.010

5. Dowdells C, Jones RL, Mattey M, Bencina M, Legisa M,Mousdale DM. 2010 Gluconic acid production by Aspergillus terreus. Lett Appl Microbiol. 51: 252-257.

https://doi.org/10.1111/j.1472-765X.2010.02890.x

6. Aamir S, Sutar S, Singh S,Baghela A. 2015 A rapid and efficient method of fungal genomic DNA extraction, suitable for PCR based molecular methods.

7. Cazar ME, Schmeda-Hirschmann G,Astudillo L. 2005 Antimicrobial butyrolactone I derivatives from the ecuadorian soil fungus Aspergillus terreus thorn. Var terreus. World J Microb Biot. 21: 10671075. https://doi.org/10.1007/s11274-004-8150-5

8. Gao XC, Lu YY, Xing YY, Ma YH, Lu JS, Bao WW, Wang YM,Xi T. 2012 A novel anticancer and antifungus phenazine derivative from a marine actinomycete BM-17. Microbiol Res. 167: 616-622. https://doi.org/10.1016/j.micres.2012.02.008

9. Rao KV, Sadhukhan AK, Veerender M, Ravikumar V, Mohan EVS, Dhanvantri SD, Sitaramkumar M, Babu JM, Vyas K,Reddy GO. 2000 Butyrolactones from Aspergillus terreus. Chem Pharm Bull. 48: 559-562. https://doi.org/10.1248/cpb.48.559

10. Schimmel TG,Parsons SJ. 1999 High purity, high yield procedure for butyrolactone I production from Aspergillus terreus. Biotechnol Tech. 13: 379-384. https://doi.org/10.1023/A:1008980325885
11. Weng YC, Sha SW, Chiou CM, Tang PC, Yang JH,Ju JC. 2007 Butyrolactone I reversibly alters nuclear configuration, periooplasmic microtubules and development of porcine oocytes. Theriogenology. 67: 509-519. https://doi.org/10.1016/j.theriogenology.2006.08.017

12. Adona PR, Pires PRL, Quetglas MD, Schwarz KRL,Leal CLV. 2008 Prematuration of bovine oocytes with butyrolactone I: Effects on meiosis progression, cytoskeleton, organelle distribution and embryo development. Anim Reprod Sci. 108: 49-65. https://doi.org/10.1016/j.anireprosci.2007.07.002

13. Leal CLV, Mamo S, Fair T,Lonergan P. 2012 Gene Expression in Bovine Oocytes and Cumulus Cells After Meiotic Inhibition with the Cyclin-Dependent Kinase Inhibitor Butyrolactone I. Reprod Domest Anim. 47: 615-624. https://doi.org/10.1111/j.1439-0531.2011.01932.x

14. Niu XM, Dahse HM, Menzel KD, Lozach O, Walther G, Meijer L, Grabley S,Sattler I. 2008 Butyrolactone I derivatives from Aspergillus terreus carrying an unusual sulfate moiety. J Nat Prod. 71: 689-692. https://doi.org/10.1021/np070341r

15. Nuclear P, Sommit D, Boonyuen N,Pudhom K. 2010 Butenolide and Furandione from an Endophytic Aspergillus terreus. Chem Pharm Bull. 58: 1221-1223. https://doi.org/10.1248/cpb.58.1221

16. Haritakun R, Rachtawee P, Chanthaket R, Boonyuen N,Isaka M. 2010 Butyrolactones from the Fungus Aspergillus terreus BCC 4651. Chem Pharm Bull. 58: 1545-1548. https://doi.org/10.1248/cpb.58.1545

17. Nong XH, Wang YF, Zhang XY, Zhou MP, Xu XY,Qi SH. 2014 Territrem and Butyrolactone Derivatives from a Marine-Derived Fungus Aspergillus Terreus. Mar Drugs. 12: 6113-6124. https://doi.org/10.3390/md12126113 